\title{
FINANCIAL SUPPORT AS A DETERMINANT OF SMALL AND MEDIUM-SIZED ENTERPRISES ECONOMIC GROWTH
}

\author{
Dejan Volf* \\ AeroGround GmbH, Flughafen München, Germany \\ Jelena Vapa Tankosić \\ Faculty of Economics and Engineering Management \\ University Business Academy, Novi Sad, Republic of Serbia \\ Svetlana Ignjatijević \\ Faculty of Economics and Engineering Management \\ University Business Academy, Novi Sad, Republic of Serbia
}

\begin{abstract}
European Union integration and revitalization of economy after the global economic crisis require small and medium-sized enterprises in Republic of Serbia to face more complex and dynamic environment which requires greater competitiveness in terms of improved quality, efficiency and management practices. However, the competitiveness of the regional SMEs is still at a much lower level compared to other European SMEs. Pointing out to the characteristics of small and medium enterprises, a logical conclusion can be drawn that state support for this sector is important. When forming the support modalities, the sector should not be viewed as a uniform whole. This paper analyses the importance of financial and non financial support for SMEs in terms of organizational capability and competiveness. Roy's test, Pearson's coefficient of contingency $(\chi)$, and multiple correlation coefficients $(R)$ are applied as univariate statistical procedures. MANOVA and discriminant analysis show a difference and clearly defined boundary between other forms of support and financial forms of support in all the analyzed units. The findings also indicate that the financial forms of SME support nfluence the SMEs organization capability and competitiveness, given that in most cases the benefits of state institutions are viewed through forms of financial support.
\end{abstract}

Keywords: financial support, non financial support, competitiveness, organizational capability, small and medium enterprises

\footnotetext{
*volf.dejan@gmail.com
} 


\title{
FINANSIJSKA PODRŠKA KAO DETERMINANTA EKONOMSKOG RASTA MALIH I SREDNJIH PREDUZEĆA
}

\begin{abstract}
Sažetak: U procesu evropskih integracija $i$ oživljavanja ekonomije nakon globalne ekonomske krize, mala i srednja preduzeća u Republici Srbiji se suočavaju sa sve složenijim i dinamičnijim okruženjem koje zahteva unapređenje konkurentnosti u smislu poboljšanja kvaliteta, efikasnosti i tehnika menadžmenta. Konkurentnost MSP u regionu je još uvek na mnogo nižem nivou u odnosu na evropski prosek. Ukazujući na odlike malih i srednjih preduzeća, može se izvući logički zaključak da je državna podrška ovom sektoru bitna. Ono što se kroz rad dokazalo jeste da, pri formiranju modaliteta podrške, ne treba ceo sektor posmatrati jednoznačno. Ovaj rad analizira važnost finansijskih $i$ nefinansijskih mera za MSP u odnosu na organizacione sposobnosti $i$ konkurentnosti. Od univarijantnih postupaka primeniće se Rojev test, Pirsonov koeficijent kontingencije $(\chi)$ i koeficijent multiple korelacije (R). Primenom MANOVA $i$ diskriminativne analize, dolazi se do rezultata koji ukazuju na razlike i jasno definisanu granicu između drugih oblika podrške i finansijskih oblika podrške u svim analiziranim jedinicama. Rezultati istraživanja ukazuju i na to da finansijski oblici podrške MSP utiču na organizacionu sposobnost $i$ konkurentnost MSP, s obzirom na to da se u najvećem broju slučajeva koristi od državnih institucija posmatraju kroz oblike finansijske podrške.
\end{abstract}

Ključne reči: finansijska podrška, nefinansijska podrška, konkurentnost, organizacione sposobnosti, mala i srednja preduzeća

\section{INTRODUCTION}

In developed economic systems, SMEs have an important place, and their contribution is not only reflected in quantitative macroeconomic indicators, but also in qualitative terms, through innovation and entrepreneurship. SMEs are the true back-bone of the European economy, being primarily responsible for wealth and economic growth, next to their key role in innovation and R\&D, with nine out of ten SMEs in the EU belonging to the category of micro enterprises with less than ten employees. According to Irwin (2007) economies with high proportion of SMEs will be more resilient to external shocks and will be more likely to have more firms which grow into larger businesses. 

ENTERPRISES ECONOMIC GROWTH

Government support for SMEs will help countries exploit the social benefits from greater competition and entrepreneurship (World Bank, 2004). Acs and Szerb (2007) argued that public policies focusing on increasing potential of human capital, upgrading technology availability, labour market reform and deregulation of financial markets are extremely important to support the growth of the SMEs. Vapa-Tankosić, Redžepagić and Stojsavljević (2013) pointed out that the economies of Western Balkan countries, on the pathway to European integration "shall depend on enhancing their efficiency and performances in industry, service and know-how. Modernizing production and raising efficiency and competitivness, accelerating structural changes toward knowledge based services, are the major generators of value added, exports and new jobs" (p.229). SMEs have become the most efficient segment of the economy in almost all countries of the world. When analyzed individually, it is concluded that they make the greatest contribution to increasing employment, gross value added and turnover. The role of these companies is especially important in transition countries that face the problem of high unemployment, insufficient competitiveness, low level of economic activity and lack of investment, and in which large inefficient state-owned companies are still present (Sekulić \& Perović, 2014). Thus, in the early 1990s, the share of these companies in the national income of Taiwan was 56\%, Italy 53\%, Denmark 46\%, Korea $40 \%$ and Sweden 30\% (Kapor, 1999). Today, SMEs are one of the leading forces of economic development because they stimulate private ownership and entrepreneurial skills, are flexible, and can quickly adapt to market changes, create diversified economic activity, contribute to trade and exports and are key factors in competitive economy (Jašarević, 2013).

This study analyzes roles, competencies and authorities of stakeholders and their particular interest in public sector support programs. Furthermore, it estimates the possible influence of every participant in the process in order to increase the effectiveness of the export assistance programs in developing countries, especially in a transition to a market economy. Thus, this empirical study can contribute to best practices of government support. In this empirical study, the authors have analyzed the importance of financial and non financial support and its influence on the benefits from state institutions and bodies, SMEs organizational capability and the SMEs competitiveness. The scope of this paper is to find the critical problems that Serbian SMEs face and promote industry support. Important contribution of this research is that majority of studies have been conducted in developed countries (e.g. USA, Canada and Western Europe) with very little attention given to support in developing countries (Julian, 2003). In the next sections the authors have presented the literature review, then explained the research method and the hypotheses, and 
presented the results of empirical research in order to confirm or reject the proposed hypotheses. Empirical data, discussion and analysis results are also presented. The final conclusions and guidelines based on research findings are presented in the end of the empirical study.

\section{LITERATURE REVIEW}

The issue of SMEs internationalization, described as the process of increasing the involvement in international operations, or especially, the process of exporting, attracts most attention from policymakers in the developed countries (Bell \& Young, 2004). In order to make the most of their strengths and minimize their weaknesses, SMEs should use certain partnership and cooperative arrangements in the process of internationalization (Todorović, 2007). Ignjatijević, Babović and Đorđević (2012) performed an analysis of comparative advantages in the exports of the Republic of Serbia and have concluded that it is necessary to make additional efforts in order to ensure brand and design visibility, product aesthetics, types of sales, packaging and adaptation to international standards. It is important to emphasize that, although they are similar in many ways, SMEs do not represent a homogeneous category. It is necessary to distinguish between SMEs that are older and those that are young because their attitude towards internationalization is also different. Namely, older companies generally follow the traditional approach to internationalization, gradually, step by step, while young companies enter more and more foreign markets more decisively, easier and faster at the same time (Rakita \& Mitić, 2012). The programs that focus on international orientation of leaders and key decision makers in SMEs are very important (Lloyd-Reason, Damyanov, Nicolescu \& Wall, 2004). Strategic management of the international distribution network can improve the competitive position of SMEs in the foreign market, and thus contribute to a greater volume of foreign sales and sales share in the international market (Vapa \& Vapa-Tankosić, 2019). Vapa, Ignjatijević and Gardašević (2015) have identified that the most important export problems for Serbian exporters are: ineffective national export promotion programmes, red tape in domestic public institutions, lack of government assistance in overcoming export problems and the existence of a strong international competition. The results suggest that the exporters have also considered their staff as qualified for the export arrangements, and that their organization of export department is on a satisfactory level ready to deliver effective communication with overseas customers, without language problems. Žunić-Kovačević, Vapa-Tankosić \& Lazić, (2016) performed a survey on export activities of SMEs in Croatia and Serbia in order to compare the 

ENTERPRISES ECONOMIC GROWTH

qualitative export performance factors related to the level of entrance to the European single market. High costs of export financing, lack of effective government programs for exporters, strong international competition and the complexity of documents for export are proven to be the most significant barriers for SMEs in Croatia and Serbia. The results have confirmed that SMEs in Serbia do not possess an export strategy, and export sales are often a result of sporadic contact from foreign markets. However, both Serbian and Croatian SMEs exporters consider themselves able to cope with competition from the EU, in terms of quality, price and design. Gurrieri and Petruzzellis (2008) point out that SMEs export performance is affected by its structural and organizational characteristics. Lautanen (2000) explores the relationship between the decision maker's age and language ability, and export performance. Knowles, Mughan \& Lloyd-Reason (2006) emphasize the language skills that make indirect contributions to international business success. The crucial role of the government in the development of successful export activities gives credibility to the studies focusing on the appraisal of public policy programmes for export promotion (Kotabe \& Czinkota, 1992; Seringhaus, 1986; Seringhaus $\&$ Botschen, 1991).

A complex relationship between export promotion programs and export performance can be explained using internationalization process theory and resource-based theory. Internationalization process theory indicates how gradual knowledge acquisition leads to greater commitment to exporting and international operations (Johanson and Vahlne, 1990). Resource-based theory proposes that competencies in the form of knowledge and expertise are critical to superior organizational performance (Barney, 1991; Coff, 1997). While these competencies are internal and are acquired by firms, export promotion programs help firms to obtain the information, knowledge, experience, and resources they need to develop an export strategy and achieve better performance (Singer and Czinkota, 1994). This suggests that government support programs help develop company and managerial capabilities such as knowledge and skills that can positively influence a firm's export strategy and performance. Yet, significant differences are found among large firms and experienced exporters in their degree of awareness of export promotion programs as large firms and experienced exporters were significantly more aware of several export promotion programs than small and medium-sized firms (Ahmed, Mohamed, Johnson \& Meng, 2002). The greater use of export assistance programs contributed to the achievement of export knowledge and product market objectives (Francis \& Collins, 2004, p.490). 


\section{METHODOLOGY}

\subsection{RESEARCH SAMPLE AND DATA SOURCE}

The study was carefully prepared and carried out by a method of survey. The questions in the survey were designed in accordance with the aims of the research (Leonidas, Palihawadana \& Theodosiou, 2011). The individual questions were answered by the respondents with scores on a Likert scale from 1 to 5 . The survey has been sent to 130 small and medium enterprises in Vojvodina in the year 2015. This number represents a small share of total SMEs in the Autonomous Province of Vojvodina (RZS, 2018), but a significant share in relation to the total number of SMEs that is successfully engaged in foreign trade in Vojvodina. All companies are privately owned (100\% privately owned, mostly up to 5 owners in the ownership structure). Out of the total number of respondents, 78 fully completed valid surveys have been received (60\% response rate) and 37 of them had export activities. After completion of the survey elaboration and processing of data was done by Statistical Package for Social Sciences. Observed variables are characteristic, interconnected and form a logical unit (C).

\subsection{DEFINING RESEARCH HYPOTHESES}

The objective of this paper is to analyse the perceived importance of financial and non financial measures for SMEs in terms of organizational capability and competiveness. Firstly, the authors have investigated how the SMEs perceive the benefits from state institutions and authorities in relation to "other forms of support" and "financial forms of support". Secondly, the perceived organizational capability of the company has been analyzed in relation to "other forms of support" and "financial forms of support". Thridly, the perceived competitiveness of company in the market has been analyzed in relation to "other forms of support" and "financial forms of support".

The following hypothesis can be derived from the research objectives and methodological approaches of this research:

$\mathrm{H} 1_{0}$ : There is no significant statistical difference between "other forms of support" and "forms of financial support" in relation to the perceived assessment of the benefits from state institutions and authorities of respondents.

$\mathrm{H}_{\mathrm{a}}$ : There is a statistical difference between "other forms of support" and "forms of financial support" in relation to the perceived assessment of the benefits from state institutions and authorities of respondents. 

ENTERPRISES ECONOMIC GROWTH

$\mathrm{H} 2_{0}$ : There is no clearly defined statistical boundary between "other forms of support" and "forms of financial support" in relation to the perceived assessment of the benefits from state institutions and authorities of respondents.

$\mathrm{H} 2_{\mathrm{a}}$ : There is a clearly defined statistical boundary between "other forms of support" and "forms of financial support" in relation to the perceived assessment of the benefits from state institutions and authorities of respondents.

$\mathrm{H}_{3}$ : There is no significant statistical difference between "other forms of support" and "forms of financial support" in relation to the perceived SMEs organizational capability and competitiveness in the market.

$\mathrm{H} 3_{\mathrm{a}}$ : There is a significant statistical difference between "other forms of support" and "forms of financial support" in relation to the perceived SMEs organizational capability and competitiveness in the market.

\subsection{RESEARCH DESIGN AND PROCEDURE}

All variables in the model are latent variables. Multi-item scales have been used to operationalize all the variables. Two construct measures of the institutional support programmes will be developed. A five-point scale was used to rate the level of benefit of the services. The level of perceived benefit was used to weigh each service used by respondents. Drawing on the literature, a number of items will be used to measure managers' attitude and perception towards organizational capability variables: locating and analyzing potential markets, acquiring market information, identifying business opportunities, contacting potential partners, understanding market needs and partners, establishing a representative market presence, establishment of business relations, acceptance of new methods and ideas, development of new products and adoption of marketing approaches and techniques and responding to actions of competitors. Drawing on the literature, a number of items will be used to measure managers' attitude and perception towards competitiveness variables: costs of raw materials as a factor of competitiveness, production costs as a factor of competitiveness, distribution and sales as a factor of competitiveness, recognition of products on the market, introduction of new products, product range, brand recognition, availability of products on the market, speed of delivery, possibility of after-sales service, provision of satisfactory quality, retention of customers/ partners, acquiring new customers/ partners and building reputation in the market. The next variable, other forms of institutional support, includes: provision of various information by state authorities, government programs and support for specific business activities, education provided by the state officials (courses, seminars, lectures, etc.), and the financial forms of 
institutional support: through loans (with a lower interest rate), subsidies, guarantees in the country or abroad and other forms of financial direct or indirect assistance. Methods of proving the existence of similarities or differences confirm the hypothesis of similarity or reject it (confirming the alternative hypothesis) i.e., indicating differences. The research methods applied were in line with the empirical studies on management in Serbia (Hristić, Grubić-Nešić \& Dudjak, 2011; Hristić, Čabrilo, Savić \& Šikoparija, 2016; Savić-Šikoparija, 2019). When testing the hypothesis, the critical value of $p$ has been used and represents the risk of conclusion. If it is determined that the $p$ value, $\mathrm{p}>0.100$, there is no reason why the initial hypothesis shall not be confirmed. For rejecting the initial hypothesis two thresholds of significance will be used. In the case when $0.10>p>0.05$ the alternative hypothesis shall be confirmed with an increased risk of reasoning, when $p<0.05$ the alternative hypothesis shall be confirmed, having in mind that there are significant differences. The multivariate analysis of variance (MANOVA) and discriminant analysis have been applied. In regard to univariate procedures the authors have applied Roy's test, Pearson's coefficient of contingency and multiple correlation coefficients (R).

\section{RESULTS AND DISCUSSION}

For the purpose of this research thematic sections have been outlined. In accordance with the objectives of the research, methodological approach and hypotheses set in this research, the difference within three thematic units will be analyzed. The features in relation to which the sample is divided into subsamples are criterion features. After analyzing the characteristics and homogeneity of the group of respondents in relation to the assessment - benefits from state institutions and bodies, it can be concluded that a statistically reliable division of all respondents into two subgroups - respondents who rated the benefits from state institutions and bodies worse and those who rated it better. $\mathrm{C} 1$ and $\mathrm{C} 4$ focus on the perceived benefits from state institutions and authorities in relation to "other forms of support" and "financial forms of support". In C2 and $\mathrm{C} 5$ the perceived organizational capability of the company has been analyzed in relation to "other forms of support" and "financial forms of support". In C3 and C6 the perceived competitiveness of company in the market has been analyzed in relation to "other forms of support" and "financial forms of support". 


\subsection{BENEFITS FROM STATE INSTITUTIONS AND BODIES}

Based on the value of $\mathrm{p}=.000$ (analysis by MANOVA) and $\mathrm{p}=.000$ (discriminant analysis), the hypotheses $\mathrm{H}_{0}$ and $\mathrm{H} 2_{0}$ have been rejected and an alternative hypotheses $\mathrm{H} 1_{\mathrm{a}}$ and $\mathrm{H} 2_{\mathrm{a}}$ have been confirmed (Table 1). This means that there is a difference and clearly defined boundaries between "other forms of support "and" forms of financial support".

Table 1

Results of MANOVA analysis

\begin{tabular}{|c|c|c|c|c|c|c|}
\hline & \multicolumn{3}{|c|}{$\begin{array}{c}\text { C1 } \\
\text { Other forms of support }\end{array}$} & \multicolumn{3}{|c|}{$\begin{array}{c}\text { C4 } \\
\text { Financial forms of support }\end{array}$} \\
\hline & $\mathbf{n}$ & $\mathbf{F}$ & $\mathbf{P}$ & $\mathbf{n}$ & $\mathbf{F}$ & $\mathbf{P}$ \\
\hline MANOVA & 11 & 7.879 & .000 & 11 & 9.682 & .000 \\
\hline DISCRIMINANT & 11 & 190.709 & .000 & 11 & 1048.773 & .000 \\
\hline
\end{tabular}

Note. Authors' calculations.

From the Table 2 it can be seen that there is a significant difference in "other forms of support". There is also a significant difference in "forms of financial support". On the other hand, there was no significant difference in "other forms of support" of respondents in the claim: Financial support through subsidies (.195). There was no significant difference in "forms of financial support" by the respondents in the claims: Information on financing (.534) and Information on literature and training (.512).

The coefficient of discrimination indicates that the largest contribution in the discrimination in "other forms of support" of the respondents in relation to the assessment of the perceived benefits from the state institutions and bodies is in Information on financing (.827). In "financial forms of support" the biggest difference of the respondents is in Information on potential export markets (.589). It should be noted that the latent characteristic is the feature in relation to which there was no difference between "other forms of support" and "forms of financial support". Latent feature in "other forms of support" is the Support through subsidies, and in "forms of financial support" is the Information on financing and Information on literature and training. 
Table 2

The significance of the difference between "other forms of support" and "financial forms of support" in relation to the SMEs perceived benefits from the state institutions and bodies

\begin{tabular}{|c|c|c|c|c|c|c|c|c|c|c|}
\hline & \multicolumn{6}{|c|}{ OTHER FORMS OF SUPPORT } & \multicolumn{5}{c|}{ FINANCIAL FORMS OF } \\
\hline & $\chi$ & $\mathbf{R}$ & $\mathbf{F}$ & $\mathbf{P}$ & $\mathbf{k . d s k}$ & $\chi$ & $\mathbf{R}$ & F & P & k.dsk \\
\hline I & .375 & .404 & 7.610 & .009 & .190 & .375 & .404 & 7.610 & .009 & .589 \\
\hline II & .388 & .421 & 8.405 & .006 & .827 & .100 & .100 & .394 & .534 & .018 \\
\hline III & .296 & .310 & 4.159 & .048 & .272 & .105 & .105 & .437 & .512 & .001 \\
\hline IV & .350 & .374 & 6.344 & .016 & .107 & .433 & .480 & 11.707 & .001 & .160 \\
\hline V & .433 & .480 & 11.707 & .001 & .289 & .433 & .480 & 11.707 & .001 & .349 \\
\hline VI & .276 & .287 & 3.494 & .069 & .025 & .402 & .439 & 9.288 & .004 & .263 \\
\hline VII & .541 & .643 & 27.538 & .000 & .414 & .375 & .404 & 7.626 & .009 & .003 \\
\hline VIII & .462 & .521 & 14.548 & .000 & .638 & .462 & .521 & 14.548 & .000 & .387 \\
\hline IX & .348 & .371 & 6.232 & .017 & .005 & .616 & .783 & 61.600 & .000 & .092 \\
\hline X & .202 & .206 & 1.733 & .195 & .237 & .465 & .526 & 14.879 & .000 & .477 \\
\hline XI & .380 & .410 & 7.898 & .008 & .739 & .460 & .518 & 14.268 & .001 & .155 \\
\hline
\end{tabular}

Note. Authors' calculations.

Legend: I - Information on potential export markets; II - Information on financing; III Information on literature and training; IV - Assistance with participation in trade fairs; V - Participation in the organized international business visits; VI - Assistance of other state agencies; VII - Participation in seminars; VIII - Advice on plans and activities; IX - Support through loans; X - Support through subsidies; XI - Support in the form of guarantees; k.dsk - Coefficient of discrimination.

\subsection{SMEs ORGANIZATIONAL CAPABILITY}

Based on the value of $p=.035 / .005$ (analysis MANOVA) and $p=.000 / .000$ (discriminant analysis), the hypothesis $\mathrm{H} 3_{0}$ has been rejected and the alternative hypothesis $\mathrm{H}_{\mathrm{a}}$ has been confirmed, which means that there is a difference between "other forms of support" and "financial forms of support" in the subsamples in regard to SMEs perceived organizational capability (Table 3). 
30 | FINANCIAL SUPPORT AS A DETERMINANT OF SMALL AND MEDIMU-SIZED ENTERPRISES ECONOMIC GROWTH

Table 3

Results of MANOVA analysis

\begin{tabular}{|l|c|c|c|c|c|c|}
\hline & \multicolumn{3}{|c|}{ C 2 } & \multicolumn{3}{c|}{ C5 } \\
\hline & $\mathbf{N}$ & $\mathbf{F}$ & $\mathbf{P}$ & $\mathbf{N}$ & $\mathbf{F}$ & $\mathbf{P}$ \\
\hline MANOVA & 11 & 2.302 & .035 & 21 & 3.240 & .005 \\
\hline DISCRIMINATIVE & 11 & 57.743 & .000 & 21 & 38.690 & .000 \\
\hline
\end{tabular}

Note. Authors' calculations.

Since $\mathrm{p}<.1$ the alternative hypothesis $\mathrm{H} 3_{\mathrm{a}}$ has been confirmed. From the Table 4 , it can be seen that there is a significant difference in "other forms of support" of the respondents found in: Locating and analyzing potential markets (.003) Acquiring market information (.002), Identifying business opportunities (.049), Understanding market needs and partners (.019), Establishing a representative market presence (.059), Adoption of marketing approaches and techniques (.032). There is also a significant difference in "financial forms of support" found in: Identifying business opportunities (.080) Contacting potential partners (.044), Understanding market needs and partners (.049), Establishment of business relationships (.009), Acceptance of new methods and ideas (.037) and Responding to actions of competitors (.088).

There was no significant difference in "other forms of support" of the respondents in: Contacting potential partners (.248), Establishing business relationships (.248), Acceptance of new methods and ideas (.420), Development of new products (.235), Responding to actions of competitors (.913). There was no significant difference between "financial forms of support" of the respondents in: Locating and analyzing potential markets (.589), Acquiring market information (.614), Establishing a representative market presence (.341), Development of new products (.381), Adoption of marketing approaches and techniques (.282). The coefficient of discrimination indicates that the largest contribution to the discrimination between "other forms of support" in relation to the assessment of the SMEs perceived organizational capability and that the biggest difference of subsamples has been shown in: Identifying business opportunities (.239) and "financial forms of support" and the biggest difference of the respondents is in: Understanding the market needs and partners (.232). It should be noted that the latent characteristic is the feature in relation to which no difference has been determined between "other forms of support" and "financial forms of support". 
Table 4

The significance of differences between "other forms of support" and "financial forms of support" in relation to the SMEs perceived organizational capability

\begin{tabular}{|c|c|c|c|c|c|c|c|c|c|c|}
\hline & \multicolumn{1}{|c|}{ OTHER FORMS OF SUPPORT } & \multicolumn{5}{c|}{ FINANCIAL FORMS OF SUPPORT } \\
\hline & $\chi$ & $\mathbf{R}$ & $\mathbf{F}$ & $\mathbf{p}$ & $\mathbf{k . d s k}$ & $\boldsymbol{\chi}$ & $\mathbf{R}$ & $\mathbf{F}$ & $\mathbf{P}$ & k.dsk \\
\hline I & .413 & .454 & 10.113 & .003 & .050 & .087 & .087 & .296 & .589 & .003 \\
\hline II & .425 & .470 & 11.050 & .002 & .114 & .081 & .081 & .258 & .614 & .114 \\
\hline III & .296 & .309 & 4.131 & .049 & .239 & .266 & .276 & 3.225 & .080 & .132 \\
\hline IV & .181 & .184 & 1.374 & .248 & .039 & .301 & .316 & 4.313 & .044 & .013 \\
\hline V & .342 & .364 & 5.956 & .019 & .001 & .296 & .309 & 4.130 & .049 & .232 \\
\hline VI & .285 & .297 & 3.778 & .059 & .200 & .151 & .152 & .928 & .341 & .000 \\
\hline VII & .181 & .185 & 1.375 & .248 & .080 & .375 & .404 & 7.628 & .009 & .025 \\
\hline VIII & .128 & .129 & .663 & .420 & .015 & .311 & .327 & 4.674 & .037 & .132 \\
\hline IX & .186 & .190 & 1.457 & .235 & .122 & .139 & .141 & .785 & .381 & .085 \\
\hline X & .317 & .335 & 4.920 & .032 & .045 & .170 & .172 & 1.189 & .282 & .124 \\
\hline XI & .018 & .018 & .012 & .913 & .034 & .260 & .269 & 3.054 & .088 & .053 \\
\hline
\end{tabular}

Note. Authors' calculations.

Legend: I - Locating and analyzing potential markets; II - Acquiring market information; III - Identifying business opportunities; IV - Contacting potential partners; V - Understanding market needs and partners; VI - Establishing a representative market presence; VII - Establishing business relations; VIII - Acceptance of new methods and ideas; IX - Development of new products; X - Adoption of marketing approaches and techniques; XI - Responding to actions of competitors; k.dsk - Coefficient of discrimination.

Latent feature in "other forms of support" is: Contacting potential partners (.248), Establishing business relationships (.248), Acceptance of new methods and ideas (.420), Development of new products (.235), Responding to actions of competitors (.913), and in "forms of financial support" is: Locating and analyzing potential markets (.589) Obtaining information from the market (.614), Establishing a representative presence in the market (.341), Development of new products (.381) Adoption of marketing approaches and techniques (.282). Analyzing the results of our research on the importance of other forms of support and financial support in relation with the perceived organizational capability we see that, of particular importance, are Information and analysis of opportunities, resources, potentials and ideas which is consisitent with the previous findings. 


\subsection{SMEs COMPETITIVENESS ON THE MARKET}

Based on the value of $\mathrm{p}=.081 / .015$ (analysis MANOVA) and $\mathrm{p}=.000 / .000$ (discriminant analysis), the hypothesis $\mathrm{H} 3_{0}$ has been rejected and the alternative hypothesis $\mathrm{H}_{\mathrm{a}}$ has been confirmed, which means that there is a difference and clearly defined boundary between "other forms of support" and "financial forms of support" in subsamples in relation to the assessment of the perceived SMEs competitiveness on the market (Table 5).

Table 5

Results of MANOVA analysis

\begin{tabular}{|l|c|c|c|c|c|c|}
\hline & \multicolumn{3}{|c|}{ C 2 } & \multicolumn{3}{c|}{ C5 } \\
\hline & $\mathbf{N}$ & $\mathbf{F}$ & $\mathbf{P}$ & $\mathbf{N}$ & $\mathbf{F}$ & $\mathbf{P}$ \\
\hline MANOVA & 14 & 1.873 & .081 & 24 & 2.671 & .015 \\
\hline DISCRIMINATIVE & 14 & 795.581 & .000 & 24 & 936.463 & .000 \\
\hline
\end{tabular}

Note. Authors' calculations.

Since $\mathrm{p}<.1$ the alternative hypothesis $\mathrm{H}_{\mathrm{a}}$ has been confirmed. From the Table 6 it can be seen that there is a significant difference in "other forms of support" in: Production costs as a factor of competitiveness (.023), Introduction of new products (.019), Brand recognition (.016) Provision of satisfactory quality (.048), Retention of customers/partners (.007), Acquiring new customers/partners (.083). There is also a significant difference in "financial forms of support" in: Distribution and sales as a factor of competitiveness (.060), Introduction of new products (.043), Brand recognition (.029), Possibility of after-sales service (.024) Provision of satisfactory quality (.068), Retention of customers/partners (.008), Acquiring new customers/partners (.083) and Building a reputation in the market (.050).

No significant difference has been determined in "other forms of support" in: Costs of raw materials as a factor of competitiveness (.274), Distribution and sales as a factor of competitiveness (.325) Recognition of products on the market (.278), Product range (.802), Availability of products on the market (.412), Speed of delivery (.143), Possibility of after-sales service (.128), Building reputation on the market (.126). No significant difference in "forms of financial support" has been determined in: Costs of raw materials as a factor of competitiveness (.199), Production costs as a factor of competitiveness (.431), Recognition of products on the market (.321), Product range (.802), Availability of products on the market (.119), Speed of delivery (.156). 
Table 6

The significance of the differences between "other forms of support" and "financial forms of support" in relation to the SMEs perceived competitiveness on the market

\begin{tabular}{|c|c|c|c|c|c|c|c|c|c|c|}
\hline & \multicolumn{1}{|c|}{ OTHER FORMS OF SUPPORT } & \multicolumn{3}{c|}{ FINANCIAL FORMS OF SUPPORT } \\
\hline & $\chi$ & $\mathbf{R}$ & $\mathbf{F}$ & $\mathbf{p}$ & $\mathbf{k . d s k}$ & $\chi$ & $\mathbf{R}$ & $\mathbf{F}$ & $\mathbf{P}$ & k.dsk \\
\hline I & .172 & .175 & 1.230 & .274 & .000 & .201 & .205 & 1.709 & .199 & .000 \\
\hline II & .335 & .355 & 5.626 & .023 & .102 & .125 & .126 & .633 & .431 & .034 \\
\hline III & .156 & .157 & .992 & .325 & .074 & .284 & .296 & 3.736 & .060 & .035 \\
\hline IV & .171 & .174 & 1.211 & .278 & .001 & .157 & .159 & 1.010 & .321 & .097 \\
\hline V & .342 & .364 & 5.959 & .019 & .395 & .303 & .318 & 4.386 & .043 & .064 \\
\hline VI & .040 & .040 & .063 & .802 & .004 & .040 & .040 & .063 & .802 & .002 \\
\hline VII & .349 & .372 & 6.268 & .016 & .003 & .322 & .341 & 5.118 & .029 & .200 \\
\hline VIII & .130 & .132 & .687 & .412 & .000 & .240 & .247 & 2.536 & .119 & .000 \\
\hline IX & .227 & .233 & 2.234 & .143 & .286 & .220 & .226 & 2.093 & .156 & .082 \\
\hline X & .235 & .241 & 2.410 & .128 & .290 & .331 & .351 & 5.478 & .024 & .153 \\
\hline XI & .296 & .310 & 4.159 & .048 & .376 & .277 & .288 & 3.526 & .068 & .136 \\
\hline XII & .381 & .413 & 8.001 & .007 & .301 & .376 & .405 & 7.672 & .008 & .218 \\
\hline XIII & .264 & .274 & 3.160 & .083 & .000 & .264 & .274 & 3.160 & .083 & .049 \\
\hline XIV & .236 & .243 & 2.437 & .126 & .167 & .294 & .308 & 4.086 & .050 & .099 \\
\hline
\end{tabular}

Note. Authors' calculations.

Legend: I - Costs of raw materials as a factor of competitiveness; II - Production costs as a factor of competitiveness; III - Distribution and sales as a factor of competitiveness; IV - Recognition of products on the market; V - Introduction of new products; VI Product range; VII - Brand recognition; VIII - Availability of products on the market; IX - Speed of delivery; X - Possibility of after-sales service; XI - Provision of satisfactory quality; XII - Retention of customers/ partners; XIII - Acquiring new customers/ partners; XIV - Building reputation in the market; k.dsk - Coefficient of discrimination.

The coefficient of discrimination indicates that the largest contribution to the discrimination in "other forms of support" of the subsamples in relation to the assessment of the SMEs perceived competitiveness on the market is in: Introduction of new products (.395); and in "financial forms of support" and in subsamples, the biggest difference is found in: Retention of customers/partners (.218). It should be noted that the latent characteristic is the feature in relation to which there was no difference between "other forms of support" and "financial forms of support". Latent feature in "other forms of support" is: Costs of raw materials as a factor of competitiveness (.274), Distribution and sales as a 

ENTERPRISES ECONOMIC GROWTH

factor of competitiveness (.325), Recognition of products on the market (.278), Range of products (.802), Availability of products on the market (.412), Speed of delivery (.143), Possibility of after-sales service (.128), Building reputation on the market (.126), and in "forms of financial support" is: Costs of raw materials as a factor of competitiveness (.199), Production costs as a factor of competitiveness (.431), Recognition of products on the market (.321), Range of products (.802), Availability of products on the market (.119), Speed of delivery (.156).

Table 7

Contribution of the whole sample according to characteristics of the subsample

\begin{tabular}{|c|c|c|c|}
\hline C4 & $\begin{array}{c}\text { Contributio } \\
\text { n \% }\end{array}$ & Score of respondents & $\begin{array}{c}\text { "Financial forms of } \\
\text { support"and ,other forms } \\
\text { of support" }\end{array}$ \\
\hline C1 & 25.527 & $\begin{array}{c}\text { Benefit from state institutions } \\
\text { and bodies }\end{array}$ & "financial forms of support" \\
\hline C6 & 15.027 & Competitiveness on the market & "financial forms of support" \\
\hline C5 & 13.775 & Organizational capability & "financial forms of support" \\
\hline C3 & 12.587 & Competitivness on the market & "other forms of support " \\
\hline C2 & 11.611 & Organization capability & "other forms of support " \\
\hline
\end{tabular}

Note. Authors' calculations.

Based on contributions (\%) of the whole sample according to the characteristics of the subsamples it can be seen from the Table 7 that the largest contribution $(25.53 \%)$ of the (C4) unit score of the subsamples favours the benefits from state institutions and bodies on the basis of "forms of financial support", followed by (C1) benefit from state institutions and bodies on the basis of other forms of support (21.47\%) and (C6) competitiveness on the basis of financial support $(15.02 \%)$.

\section{CONCLUSION}

In this empirical study, the authors have analyzed how SMEs perceive the importance of institutional financial and non financial support and its influence on the organizational capability and the competitiveness of SMEs. A sample of 78 SMEs was surveyed. All the respondents were divided into two subgroups respondents who rated the benefits from state institutions and bodies worse and 
those who rated them better. In accordance with the previously established research objectives, methodological approach and hypotheses, the difference within three logical units was analyzed. By applying MANOVA and discriminant analysis, we found that alternative hypotheses H1a, H2a, H3a have been confirmed. The results of the contribution of the whole sample show that most repondents favour financial form of support from state institutions.

The findings indicate that the financial support is perceived to impact the SMEs organization capability and competitiveness. It can be concluded that institutional financial and non-financial support is particularly important for SMEs as such, and that it must be comprehensive, systematic and coordinated. This research generally confirms the literature (Ahmed, Mohamed, Johnson \& Meng, 2002; Crick \& Czinkota, 1995; Francis \& Collins-Dodd, 2004; Day \& Wensley, 1988; Murray, Gao, \& Kotabe, 2010) but comes to some original conclusions. This empirical study has identified the impact of various measures that should be expected from insitituional support. Its importance is primarily directed at SMEs enhancement of resources and capabilities. Considering the importance of future SMEs internationalization and creation of new, innovative SMEs for small and open economies like Serbia, this finding can lead to a creation of adequate institutional support measures and instruments, aimed at the development of more competitive SMEs, which should be a priority for public policy creators. Therefore, the institutional support for SMEs is particularly important and the adequate institutional infrastructure model is still needed to enhance the transition into market economy. These findings also suggest that SMEs are aware of the importance of institutional financial support. This paper emphasize the importance of the studies focusing on the appraisal of the importnace of the policy programmes for SMEs development stressing the crucial role of the government support policy.

\section{REFERENCES}

Acs, Z. J., \& Szerb, L. (2007). Entrepreneurship, economic growth and public policy. Small Business Economics, 28, (2-3), 109-122.

Ahmed, Z. U., Mohamed, O., Johnson, J. P., \& Meng L. Y. (2002). Export Promotion Programs of Malaysian Firms: An International Marketing Perspective. Journal of Business Research, 55(10), 831-43.

Barney, Jay B. (1991). Firm Resources and Sustained Competitive Advantage. Journal of Management, 17(1), 99-120. 

ENTERPRISES ECONOMIC GROWTH

Bell, J. C., \& Young, S. (2004). Small firm internationalisation and business strategy. International Small Business Journal, 22 (1), 23-54.

Coff, R.W. (1997). Human assets and management dilemmas: Coping with hazards on the road to resource-based theory. Academy of Management Review, 22, 374-402.

Crick, D., \& Czinkota, M. R. (1995). Export Assistance: Another Look at Whether We Are Supporting the Best Programs. International Marketing Review, 12(3), 61-72.

Day, G. S., \& Wensley, R. (1988). Assessing Advantage: A Framework for Diagnosing Competitive Superiority. Journal of Marketing, 52(4), 1-20.

Francis, J., \& Collins-Dod, C. (2004). Impact of Export Promotion Schemes on Firm Competencies, Strategies and Performance: The Case of Canadian High-Technology SMEs. International Marketing Review, 21(4/5), 474-95.

Hristić, D., Grubić-Nešić, L., \& Dudjak, Lj. (2011). The differences in approaching management by managers of different gender: An example from Serbia, African Journal of Business Management, 5(26), 10769-10775.

Hristić, D., Čabrilo, S., \& Savić Šikoparija, T. (2016). Exploring the impact of sociocultural factors on positioning women in management. Poslovna ekonomija - Časopis za poslovnu ekonomiju, preduzetništvo i finansije, 19(2), 86-105.

Ignjatijević, S., Babović, J., \& Đorđević, D. (2012). Balasa index in determining comparative advantage in the export of agricultural products. Teme, 36(4), 1783-1800.

Irwin, D. (2007). Financing Entrepreneurship at the Regional and Local Level in South-East Europe. OECD Papers: Promoting Entrepreneurship in South-East Europe - Policies and Tools, 6(12), 15-17.

Jašarević, A. (2013). Mala i srednja preduzeća u Srbiji u eri globalizacije. Ekonomika, 59(1), 101-113.

Johanson, J., \& Vahlne, J. E. (1990). The Mechanism of Internationalization. International Marketing Review, 7(4), 11-24.

Julian, C. C. (2003). Export marketing performance: A study of Thailand firms. Journal of Small Business Management, 41(2), 213-221.

Kapor, P. (1999). Značaj malih izvoznika za jugoslovenski izvoz. U: M. Kovačević i H. Hanić (ur.), Ekonomsko finansijski odnosi sa inostranstvom: 
moguće alternative $u$ funkciji obnove $i$ razvoja jugoslovenske privrede: savetovanje jugoslovenskih ekonomista (str. 96-102). Beograd: Naučno društvo ekonomista Jugoslavije.

Knowles, D., Mughan, T., \& Lloyd-Reason, L. (2006). Foreign language use among decision makers in successfully internationalized SMEs. Journal of Small Business and Enterprise Development, 13(4), 620-641.

Kotabe, M., \& Czinkota, M.R. (1992). State government promotion of manufacturing exports: gap analysis. Journal of International Business Studies, 23(4), 637-658.

Lautanen, T. (2000). Modeling small firms' decision to export - evidence from manufacturing firms in Finland in 1995. Small Business Economics, 14(2), 107-124.

Leonidas L. C., Palihawadana, D., \& Theodosiou, M. (2011). National Export-Promotion Programs as Drivers of Organizational Resources and Capabilities: Effects on Strategy, Competitive Advantage, and Performance. Journal of International Marketing, 19(2), 1-29.

Lloyd-Reason, L., Damyanov, A., Nicolescu, O., \& Wall, S. (2004). Internationalisation Process, SMEs and Transitional Economies: A FourCountry Perspective. International Journal of Entrepreneurship and Innovation Management, 5(3-4), 206-226.

Lu, J. W., \& Beamish, P. W. (2002). The Internationalisation and Growth of SMEs. Strategic Management Journal, 22(6-7), 565-586.

Murray, J. Y., Gao, G. Y., \& Kotabe, M. (2010). Market Orientation and Performance of Export Ventures: The Process Throught Marketing Capabilities and Competitive Advantages. Journal of the Academy of Marketing Science, 39(2), 252-69.

Rakita, B., \& Mitić, S. (2012). Networking and clustering as contemporary strategies of business internationalization. U: S. Lovreta, M. Petković i J. Janićijević (ur.), From Global Crisis to Economic Growth. Which Way to Take? (str. 47-78). Belgrade: Faculty of Economics.

RZS (2017). Preduzeća u Republici Srbiji prema veličini. Beograd: Republički zavod za statistiku.

Savić-Šikoparija, T. (2019). Korporativna odgovornost preduzeća u internom $i$ eksternom komuniciranju. (Doktorska disertacija). Novi Sad: Fakultet tehničkih nauka, Univerzitet u Novom Sadu. 

ENTERPRISES ECONOMIC GROWTH

Sekulić, M., \& Perović, V. (2014). Značaj izvoznih aktivnosti za poslovanje industrijskih preduzeća. Zbornik radova Fakulteta tehničkih nauka, 28(6), 1374-1377.

Seringhaus, F. H. R. (1986). The impact of government export marketing assistance. International Marketing Review, 3(2), 55-65.

Seringhaus, F. H. R., \& Botschen, G. (1991). Cross-national comparison of export promotion services: the views of Canadian and Austrian companies. Journal of International Business Studies, 22(1), 115-133.

Singer, T. O., \& Czinkota, M. R. (1994). Factors Associated with Effective Use of Export Assistance. Journal of International Marketing, 2(1), $53-71$.

Todorović, L. V. (2007). Mala i srednja preduzeća i njihov uticaj na izvoz. Ekonomska diplomatija, 2(7-8), 75-84.

Vapa, B., \& Vapa-Tankosić, J. (2019). Management of the international distribution channels in the SMES international business strategy. School of Business, 1/2019, 32-46.

Vapa-Tankosić, J., Ignjatijević, S., \& Gardašević, J. (2015). Evidence of Export Perfomance Determinants prior to EU Integration: Is The Single Market too far away? Teme, 39(4), 1257-1276.

Vapa-Tankosić, J., Redžepagić, S., \& Stojsavljević, M. (2013). Trade, Regional Integration and Economic Growth: MEDA Region and the Western Balkan Countries. In Financial Integration (pp. 215-229). Springer, Berlin, Heidelberg.

World Bank (2004). Can intervention work? The Role of Government in SMEs success. Washington, DC: The World Bank.

Žunić-Kovačević, N., Vapa-Tankosić, J., \& Lazić, B. (2016). The mechanism of SMEs internationalization towards the EU single market perspective. In D.Rabat, K.Černe and Zenzerović R. (Eds.) European Union Future Perspectives: Innovation, Entrepreneurship and Economic Policy (pp. 43-59). Pula: Juraj Dobrila University of Pula.

Delivered: 10.03.2020. Accepted: 12.10.2020. 